\title{
Information Message Of Kindness On The Architecture Gate Of The Palace Solo
}

\author{
Ayub Muktiono \\ Department Arsitektur, Fakultas Teknik Universitas Krisnadwipayana, Jakarta, Indonesia \\ Corresponding Author: \\ Email : ayubmuktiono@unkris.ac.id
}

\begin{abstract}
.
Human life in the natural world could not live alone. To achieve the goal of living together, the man will always interact with each other in society. Communication and information to be very important in communicating. Communication in the community can be done both verbally and nonverbally. Communication in non-verbal considered more timeless than verbal communication. One of the non-verbal communication which is carried out by the public is in the form of a building. Solo is a work of architecture that has a message non-verbal information from the king to his people. One part of the building of the Palace Solo that has the message information is on the door of the gate of the Kori Apit. With the method of approach to the interpretation of the shape of the marks found on the door of the gate of the Kori Flank and linked with the culture of the people of Java, then obtained the meaning of the information message that is very wise of the king that is delivered to his people.
\end{abstract}

Keywords: Gate gate, Architecture, Information.

\section{INTRODUCTION}

The city of physically represents the identity of the community. Up with notice of the condition of the physical one city will be able to look how the civilization of the community. Remodeling of the elements of the pedestrian, the availability of landmark, atmosphere of peripheral (edge), open space to gather (node) and one area is a part of-part of the elements of the city is able to give the image life against a city (Kevin Lynch,1969). The existence of the city of Solo, this started when Sunan Pakubuwana II, King of the Mataram Sultanate, shifting the position of the king from Kartasura to the Village of Sala, a village not far from the edge of the Bengawan Solo, because the castle Kartasura ruined as a result of the raid rebels.

Sunan Pakubuwana II bought the land from the glens of the Village of Sala, namely Kyai Sala, size of 10,000 dollars (gulden Netherlands) to build the palace of Mataram new. Officially, the palace of Mataram new named Keraton Surakarta Hadiningrat and started in on the 17 of February 1745. This date was later set as the birthday of the City of Surakarta. Agreement Giyanti that it is signed by Sunan Pakubuwana III, the Netherlands, and the Prince of the Ruler on 13 February 1755 divide the territory of Mataram into two namely Kasunanan Surakarta and the Sultanate of Yogyakarta. Further the territory of Kasunanan Surakarta is on the wane, because the Agreement Salatiga held on 17 March 1757 cause Raden Mas Said 
acknowledged as a prince of independence with the territory the status of the duchy, which is called by the name of Praja Mangkunegaran. As the ruler of Mangkunegaran, Raden Mas Said the title of Adipati Mangkunegara.

The palace is essentially a symbol of status and power from the authority. Similarly, keraton Solo is a symbol of the power of the kingdom of Surakarta. Keraton Surakarta (called Solo) is composed of the gate of the outer, then the buildings of the palace complex, namely; the palace Kamandungan, tower Sanggabuana, ward Smarakatha, ward Mercukundha, building Kedhaton, Hall Sasana Sewaka as well as equipped with north square and south square. Besides, there is the building of the Great mosque which is located in the west of the palace is the unity of a complex of keraton Solo. Considering the many buildings of the palace Solo that became the landmark of the city of Solo, the authors chose the building of the gate of the palace as a case of landmark buildings that became the object of research, the selection of the gate of the royal palace that became the focus of research with the argument:

1. The door of the gate of the palace is a complex part of building the palace into the veranda of the palace which was first seen by the public.

2. The door of the gate of the palace is the part that is easily found by the community without having to pass through the area authority of the palace and does not require the permission of the courtiers.

3. The door of the gate of the palace is a representation of the existence of the power and authority of the king the ruler of the kingdom that existed at that time.

4. The door of the gate of the palace as a medium of communication of the earliest of the king to his people, the community through its shape.

5. The king's message to his people can be easily seen by the people of the form of the gate of the palace.

In the science of architecture is very important the existence of the limit as forming one space. In each city limits there is a Gate Kasunanan which was founded around the year 1931-1932 during the reign of Sunan Pakubuwana X in Kasunanan Surakarta. Gate Kasunanan was established as a border and the entrance gate of the capital city of the kingdom (Surakarta) with the region around. Gate Kasunanan not only founded on highways, but is also founded on the edge of the Bengawan Solo river, which in time became the pier and the place of crossing (in Mojo/Silir). The size of the Gate of the transfer to the airport consists of two sizes, large and small. Gate Kasunanan large size established in a big way. Gate Kasunanan size can be seen in Grogol (south), Rows (west), and Jurug (east). While the Gate Kasunanan small size can be seen in the area of the RS cowshed (north), the way the direction of the Tray in Solo Baru (south), Makamhaji (west), and in Mojo/Silir. Gate Kasunanan large also has the inscription time of the establishment of the gate.

Of the many portals that exist on the border of the City of Solo, the researchers chose a gate that is able to give meaning and has to be handle life of the community, especially the leader or head of the region, namely gate Gate Kori Gapit. By looking at 
the shape of the gate Kori Apit tried to download to interpret the meaning of the shape and and rinupa contained in the building Gate Kori Squeeze the.

\section{METHODS}

Stephen W Littlejohn (2009 ; 201), a message is also determined by the presence of symbols, signs, and partly by the process of interpretation used by the recipient of the message. The recipient of the message in the gate as a sign here is the community. The gate is a physical limit sign from a region. It means that if we have passed through a gate, then we have entered into different regions. Review of science communication, the gate here is able to convey the message through its existence. Ontologically gate-gate located in the City of Solo is to explain its existence as a territorial boundaries of the Solo that became the territory of the authority of the King of Surakarta kingdom at that time. Up to this time the gate is still standing and the people of the City of Solo and the surrounding area is very understanding about the existence and meaning of the gate. Communication involves an understanding of how people behave in creating, exchanging, and interpreting messages. And therefore, research in the field of science communication using coverage-coverage methods from the scientific to the humanist, Thomas B. Farrell, Beyond Science; Humanities Contribution to communication Theory, in Handbook of Communication Science, ed, Charles, R Berger and Steven H Caffee, Newbury Park, CA; Sage, 1987 ; 123-139).

The gate in this case as the building has been give a message to the surrounding community. Message delivered at least as a sign of territory from the reign of the kingdom of Surakarta under the authority of the king. The investigation about the symbols of the form of thought is important in the theory of communication. Field of science communication a study of these symbols are referred to as semiology or semiotics. It cannot be denied that the gate has been presented above in terms of the science communication can be performed research through the theories of science communication, especially semiotics or semiology. The investigation of semiotics, represent objects outside the sign itself. The investigation of the signs not only provide a way to view the communication, but rather has a strong influence on almost all perspectives are now applied to the theory of communication. (Wendy Leeds-Hurwitz, Semiotic and Communication; Signs, Codes, Cultures, Hillsdale, NJ, Lawrence Erlbaum, 1993 ; 53). See at a glance from the shape of the building the door of the gate, the visible presence of rinupa or architectural ornaments which of course it has a meaning. In signs and symbols contained in the ornaments of the gate of the meaning of which is able to convey a message to people who see it.

Confirmed also by Arthur Asa Berger in Signs in Contemporary Culture, An Introduction to Semiotics, (Salem, WI ; Sheffield, 1989 ; 82). The mark indicates or signifies some other conditions. While the symbol that usually indicates a sign of the complex with many meanings, including the sense of being special. Likewise on the 
building of the gate of the City of Solo is filled with ornaments signs and symbols that requires more research in order to get more meaning and depth. Research conducted of using the theory of science communication related to the field of architecture. Some experts give the difference between a symbol and a sign. Sign in reality has a clear reference to something, while the symbol is not. Most thoughts experts semiotics involves the idea of a basic triad of meaning, which asserts that meaning arises from the relationship between three things ; objects (target); human (interpreters); and the sign (meaning outside the sign itself). The meaning depends on the picture or the mind of a person in relation to the signs and the objects that are represented by the sign.

According to its insidious g, in the Semiotics of Visual, Susann Vihma (2009; 9), the design of dealing with the visual elements and has the alphabet of the visual, such as lines, colors, textures, and other. This is the sign-a sign similar to a mark in the written language. Designer or planner or designer using a visual language which is poorly developed and poorly understood. All the steps to make a statement. A product planning of sending the message information. The construction of a gate of course through the process of designing or planning. Similar to the written language, even though visually more complicated in the use of line, color, shape, form and texture. Alphabet visual of the different signs and symbols to produce a type of a statement made by the quality of the two-and three-dimensional object shape. How the gate operates and plays a role in science communication ? Chambers stated that communication theory is based on four components; a).message signs; b).output (output), transmission media; c).input (input) or receptions; and d).response. The gate operates in a linear manner since designed built and created directly convey the message, then the message is accepted by the community that see the presence of the gate. The next message received by the public who saw it got a response over the buildings of the gate.

Wendy Leeds-Hurwitz, Semiotic and Communication; Signs, Code, Cultures, Hillsdale, NJ, Lawrence Erlbaum, (1993 ; p53). The investigation of the signs not only provide a way to view the communication, but rather has a strong influence on almost all perspectives are now applied to the theory of communication. The door of the Gate of the Palace Solo as a sign, in harmony with the message that he brought, quite precise and clear to be able to talk effectively (easy and impressive) for the people of the recipients of the message. The door of the Gate of the Palace Solo such as the reality of visual communication as a system of fulfillment of human needs in the field of visual information through symbols that are invisible to the eye. The dynamics of visual communication today is experiencing rapid development. Almost in all fields, disciplines and activities. Coat of arms-the coat of arms, or visual symbols present in the form of images, a system of signs, corporate identity, until the display range of products in a shopping center with a variety of attraction.

Signs associated with its designee or sign definitely has what it represented. He also stressed the signs actually never stand alone, always be a part of a system of signs that 
is set in a certain way. Sign (sign) found on the door of the gate of the Palace Solo is something of a physical nature, can be perceived by our senses, which saw it. A sign refers to something beyond the sign itself and relies on the introduction by man as a user who saw the gate, so it can be called "signs". While it's meaning is found on the door of the gate of the Palace Solo, is the result of "tagging". Meaning on the door of the gate of the Palace Solo is not the concept of absolute and static that can be found in the packaging of the message. Meaning the gate of the Palace Solo is an active process. The semiotician use verbs such as create, evoke, or negotiate to refer to the process of meaning of a sign. Then the meaning on the signs found on the door of the gate of the Palace Solo that also is the result of a dynamic interaction between the signs are there, the interpretant and the object. While historically, the meaning of the gate of the Palace Solo position may be changed with the passage of time.

The study of semiotics of the most important issues related to the mark shows how signs make a difference in the social life of human. This branch has the most important influence in the theory of communication because of signs and sign systems is seen as a tool of human communication. Refortified by Karen Tracy \& Kathleen Haspel, in Language and Social Interaction, Its Institution Identity, Intelectual Landscape adnd Dicipline Shifting Agenda, Journal of Communication. Meaning and marks found on the door of the Gate of the Palace Solo is very essential in the study of communication. At the time of the gate of the Palace Solo viewed in the perspective of communication studies, mean we talk about communication and relationship with signs and meaning. While in the study of communication learn the signs and meanings categorized as semiology (semiotics). Therefore, the view and search for meaning in the sign of the Gate of the Palace Solo entrance in the study of communication science perspective of semiotics. Indeed, communication in a semiotic perspective is as the generation of meaning (the generation of meaning).

Thomas Sebeok, in The Doctrine of the Sign, Frontiers in Semiotic terms, Bloomington, Indiana University (1986), important signs for a number of attention will be a wide range of communication, but of course that means in view on the understanding and meaning. The generation of meaning to understand the message contained on the door of the Gate of the Palace Solo indeed through the process. Approach to the generation of meaning through this process, according to John Fiske, is very interested in how the door of the Gate of the Palace Solo as the sender of the message and the man as the recipient of the message, perform the process of constructing the message (encode) and translate it (decode). Approach meaning of the sign on the Gate of the Palace Solo through this process, usually interested in things such as efficiency and accuracy. And view communication as a process with a sign on the door of the Gate of the Palace Solo, will affect the state of mind of the human person who saw him as the recipient of the message.

The design covers the entire field of design, required the formation of the structure 
of the form and pragmatic society (Horst Oehlke, 2009). The door of the Gate of the Palace Solo also true is one manifestation of a symbol or visual language in it is contained the structure of the way such as: line, color, and composition. His whereabouts are grouped in the category of the non-verbal communication, he was distinguished with the verbal language of tangible writing or speech. In graphic design, which later evolved into the visual communication design utilizes many carrying capacity of the image as the symbol of visual messages, in order to streamline communication. Efforts to utilize the emblems of the visual depart from the premise that visual language has characteristics that are typical of even very special to cause certain effects on the observer. Things so there are times when it is difficult to be achieved when expressed with verbal language.

\section{RESULT AND DISCUSSION}

The location of the Gate Kori Surround the Solo is easy to find because before entering the Palace Solo, must pass through the Gate the Gate Kori Squeeze it. Slamet Riyadi street is the main street of the City of Solo. Towards the Gate Kori Apit Keraton Solo, easily accessible from Jalan Slamet Riyadi.in jalan Slamet Riyadi is so entering the Gate Gladag will arrive at the Alun-Alun Lor, which is an open field located in the north of the Palace Solo. From the Alun-Alun Lor Keraton Solo if you will go to Solo, then it will pass through the gate again. The gate is called the Gate of the Kori Apit. Gate Kori Wedge consist of a white building like a thick wall high and middle perforated with the form of straight-straight with a variety of ornaments rinupa at the top and decorated with a few ornaments on the edge of the wall. After passing through the Gate Kori Squeeze it, then looks to the main building of the Palace Solo.

The gate Kori Apit is composed of a pair, or two (2) buildings gate in the east and the west front lawn of the building Kamandungan, namely the main building to enter the palace.

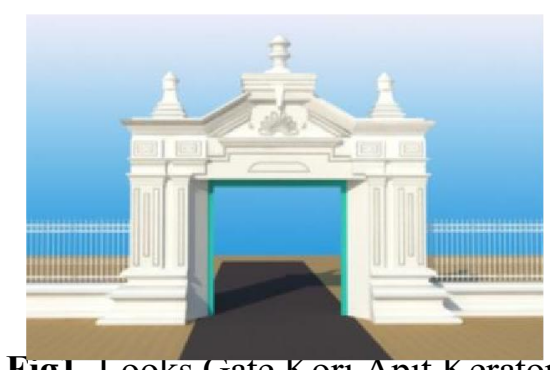

Fig1. Looks Gate Kor1 Apit Keraton

Building a gate Kori Apit is already located in the area of the palace. Gate Kori Apit this be a sign of the boundary between the space that is still very common (public) is the alun-alun Utara (Lor), with a space that is more private, although that is still rather common, page building Kamandungan. The region in term of the palace was given the name Brajanala. 


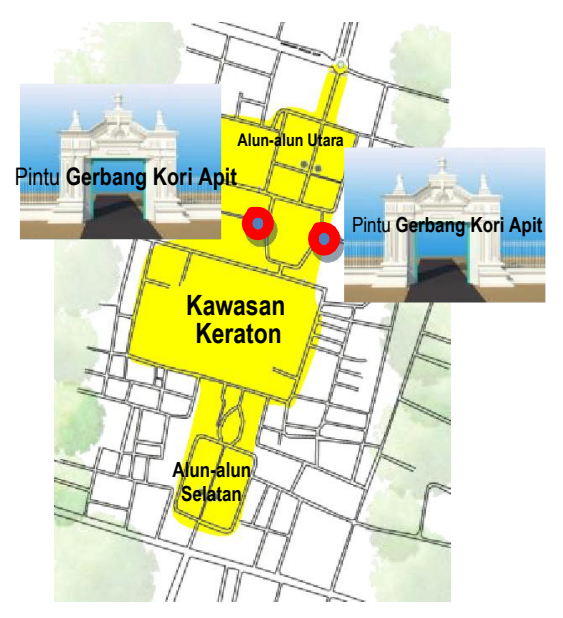

Fig 2. The Location Gate Of The Kori

The gate Kori Apit this show is private characterized by the size of the width of the gate that is narrow compared to the gate Gladak which is still more common (public). If the gate Gladak current can be passed 4 cars, then the gate Kori Apit this can only be passed by one car. The function of the gate is actually not only physical but also psychological. Physically the gate be a barrier between the outside and the inside. This separation serves to the efforts of the security and surveillance for the guests who come to visit can be controlled and supervised. Psychologically gate, also has a protective dominant so people become reluctant to enter it if it does not have a specific purpose with the owner of the area or the owner of the space in it. Some functions of the gate associated with the existence of a space is ; a). as a sign, b). as a hint, c) as the identity, d). as aesthetic and e). as the orientation. With the functions that exist, then the shape of the gate has a variety of shapes. In this study, the gate of which is becoming the focus of research is the gate of the Palace Solo.

\section{a. As a sign of.}

Physically the gate as a tent territorial boundaries of a region. The gate can also as a sign of the limits of the power or authority of a leader or government. If the modern era such as now, a sign of power or a sign of ownership can be in the form of a letter or certificate, then, in antiquity, the ownership of the authority and power of the government of a kingdom of physically characterized by the presence of a building gate. And therefore, according to Thomas B. Farrell, Beyond Science; Humanities Contribution to communication Theory, in Handbook of Communication Science, ed, Charles, R Berger and Steven H Caffee, Newbury Park, CA; Sage, 1987 ; 123-139), associated with the gate in this case as the building has been giving message of the sign to the surrounding community. The ownership of the gate can of elements of the institution, an element of the institution or government can even consist of a private individual. The door of the gate of the institution or government can often be 
encountered in almost every area. Similarly, the gate of the individual in the form of regol or gate which was at the time will enter the yard of a house.

The material of the gate also show the existence of the authority of their owners. At the time of Jawa classic first, the gate with the rock material used for the gate of the kingdom, duchy or a castle/palace. While the gates to the property of private individuals and the main structure using wood or bamboo. Therefore, the gate-the gate belonging to private individuals or almost no relic of antiquity that remains can be seen today. The door of the gate of the palace Solo in this study is made of rock material because it is the gate of the palace. The door of the gate as a sign that someone will be entering the territory of the palace. Sign delivered by the door of the gate of the palace each gate Kori Apit have different markings. Different sign on the door of the gate of the gate that is because the function of the gate is indeed different.

b. As the instructions.

The gate also serves as a guide to mankind, or subjects who saw it. The instructions that meant that the gate is able to give a message to the humans as the subject is looking. The message delivered is of course regardless of the physical form and rinupa found on the door of that gate. Stephen W Littlejohn $(2009 ; 201)$, a message is also determined by the presence of symbols, signs, and partly by the process of interpretation used by the recipient of the message. The recipient of the message in the gate as a sign here is the community. The gate is a physical limit sign from a region. It means that if we have passed through a gate, then we have entered into different regions. The gate Kori Apit physically also able to provide instructions other instructions have entered a territory authority or power. These instructions, among others, as the instructions of identity and identity, instructions, attention, instructions, aesthetic and instructions to be conveyed by the designer or create the gate.

\section{The Message of Kindness}

Gate Kori Apit is on the front page Brajanala before entering the main building of the Palace Solo. Gate Kori Apit there are two, namely the East and West page Brajanala. Gate Kori Flank flank the East and West gates of the page Brajanala. Brajanala terms of the meaning he said, braja means hard or steady and nala means heart. The area is called the page Brajanala with gate Brajanala gives meaning to that which has entered through the gates Brajanala flanked by the Gates of the Kori Apit, must already have the heart of a steady facing the king.

See the shape of the gate Kori Apit is the geometric lines straight-straight, no lines curve. According to the theory of architecture, (Sukatno ; III-29) that the straight lines give the impression of a firm, stable, sturdy with confidence while curved lines give the impression of soft, flexible not static. Linked with the shape of the gate Kori Apit which have the form of straight and straight lines without the arch, giving the impression that the gate Kori Apit this is firmness, the strength of a rigid and stable. So the impression is in accordance with the name of the page Brajanala which have been described in this section before. Kori Apit have some rinupa important to have a 
message as a sign. Among them are the shoots of the umbrella, shoots a spear, symbol of the rising sun and profile ornaments. At the peak of the Arch Kori Apit there are 3 (three) rinupa, which one shoots the umbrella of the kingdom and the two shoots the spear of the kingdom. Shoots the umbrella of the royal palace in the center and flanked by two shoots the spear of the kingdom.

The shoots of the umbrella gives the sense that the umbrella as a protection from the heat and rain. In particular gives the message that the kingdom of jumenengan Susuhunan Pakubuwana as a king that always gives protection to all his people. Giving shelter, a sense of security, protection against disorders of criminality and crime. Form shoots umbrella with rinupa curved round and circular, is linked with the theory of architecture, which has been described above gives the message that in providing protection and protection to the people should be with the attitude of softness and gives the shade a sense of security to the public, Solo. Associated with providing protection and security, king of assigning decision in upholding the truth and punish justly. Therefore, the position of the tops of the umbrella as a symbol of giving shelter is in the middle. The position of the middle shows that the king is in the middle position in the event of dispute, so that the king must be fair, impartial to the parties who are demanding justice and beg for protection or protection to the king. The king is positioned central in deciding sustu case, the king is also independent in analyzing a dispute.

Shoots umbrellas at the Gate Kori Squeeze are the most high or are at the peak top Gate Kori Squeeze it, indicating that the aegis and protection to the people of the community of Solo is the most important thing to strive for and maintained. As the main purpose of the main tasks in upholding justice and realize a prosperous society, with softness, shade and manners shown through the form of shoots umbrella consisting of curved lines that soft.

Shoots a Spear on top of the Gate Kori Apit.

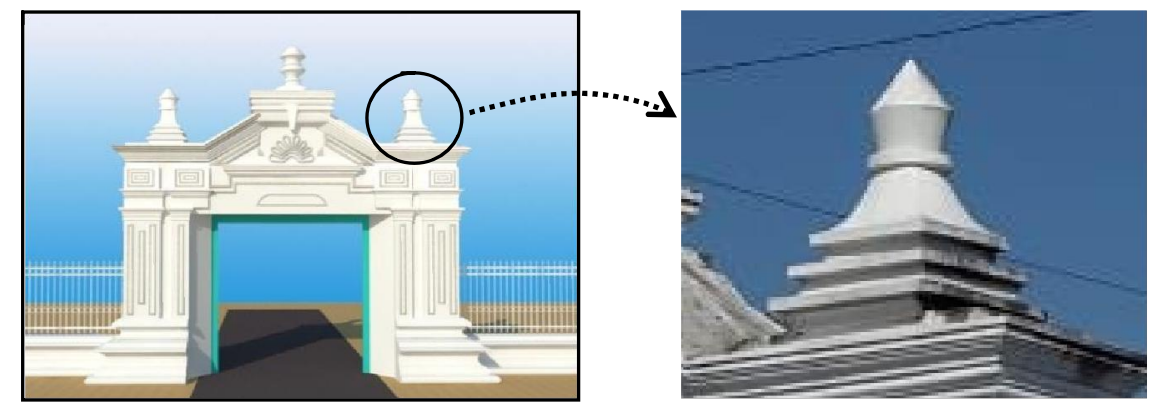

Fig 4. Rinupa Shoots a Spear at the Gate Kori Apit

The rinupa shoots umbrella kingdom there are rinupa other at the top of the Gate Kori Apit that shoots a spear of the kingdom. Different shape with the shoots of the umbrella that consists of a form of curved and circular, the shape of the helm lance 
royal-shaped taper sharply in part it is based on by the geometric arrangement of the quadrilateral a square with straight lines and rigid. Shoots a spear taper gives the meaning of the message that the king should dare to punish or to sanction parties or anyone who is wrong in a dispute. The cornerstone of shoots lance a geometric rectilinear, with lines straight has a meaning that sanctions or punishment meted out to the wrong must be implemented explicitly. However the position, shoots the spear that is at the bottom of the shoots of the umbrella gives the message however that penalties or sanctions that are set to the guilty is the assessment with emphasis on softness and in order to protect the whole community of the people of Solo.

Shoots the spear of the kingdom at the Gate Kori Apit contained in the left and right of the top of the gate flanking shoots the umbrella of the kingdom. Shoots the spear of the kingdom amounted to 2 (two) give the meaning of a pair, meaning that in the nurture and protect the public and the people of the Solo should be fair between good and evil, crime and kabajikan. And decrees which had been decided by the king to be enforced or executed in the firm, which is denoted by rinupa shoots the spear of the kingdom.

Linked with the culture of the society Solo, then the signs are expressed in the rinupa Gate Kori Apit is indicated in the cultural events on the Grebeg Syawal and Warning Sekatenan. In the event Grebeg Syawal and Warning Sekatenan, there is always a cone large, umbrella kingdom and the spear of the kingdom brought or paraded in the activities of the celebration. Cone large symbolizes the gunungan wayang purwa inherited by Sunan Kalijaga and used for the rituals of the religion of Islam in Java. Umbrella kingdom that is included in the celebration symbolizes that the king was to provide protection and shelter to his people that always come true well-being, peace and became a man who uphold moral values that are passed Sunan Kalijaga. Next also brought also in celebration of the grebeg is the spear of the kingdom. Where the spear of the kingdom gave a sign of firmness and steadiness of the king to always uphold justice, truth and virtue to support the softness and justice in creating welfare for the people of Solo.
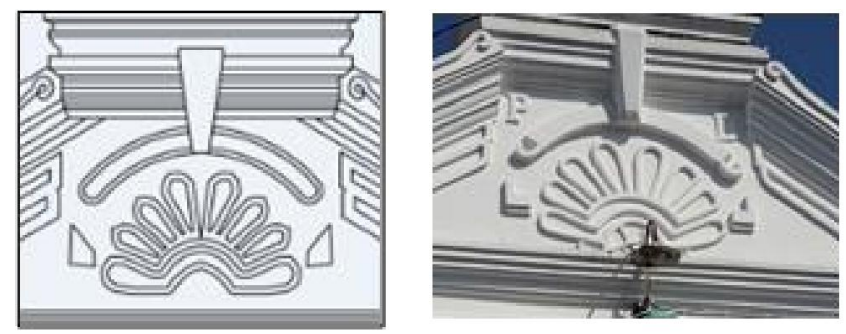

Fig 5. Rinupa the Sun Rises at Kori Apit

Rinupa next at the top of the gate Kori Apit is a form of rinupa sunrise who are in the middle of the top right in a line symmetrical gate. Rinupa-shaped image of the rising sun has a message meaning that the sunrise is at the time of the morning. At a time like this almost all of God's creatures start the day or start the process naturally. Man began 
with his work, animals start with foraging and plant begins with the process of growth with its photosynthetic. This time is time with the situation of the state with high spirits. Similarly, the meaning of the message conveyed in the rinupa form a picture of the sunrise. To realize the aegis and protection to its people must be in high spirits. Although the age of the king or someone is old, but the spirit or motivation must be maintained, should not be sagging. Sunrise is a time of beginning the sun is shining, the message also gives the meaning that in the morning is the time that still there are many expectations that can be achieved to realize what the desire.

The width of the Gate Kori Apit which is not more than 3.7 meters show that that can fit into the page Brajanala is only one vehicle, one by one. In antiquity means that can be entered about the size of a train of horses, can not be crossed. Size thereby showing that only people who already have the intention of dogged determination and a willingness hard that can be to the king to get provisions, meaning that the more narrow the size of the width of the gate shows there is a filter or a watchful eye to be able to enter into the territory of the palace.

\section{CONCLUSION}

The study etnosemiologi is done in the context of the approach to the culture of the people of Java. Culture of the people of Java is used as the approach to the theory of semiology as a pen analysis, obtained some conclusions as follows :

1. Gate or Gate has a meaning that is very important and strategic. Very important because it is able to act as a medium to deliver the message or "stories" from the leadership to the people. Very strategic because it is the gate or Gate can be used as the identity or the identity of a region (city) which is a mirror of the culture of the people.

2. Shape, ornament or rinupa contained in the Gate Kori Apit admonished, the doctrine that the leader, king or head area must provide shelter to the people. Leaders also need to be firm and uphold the truth. Sentencing is needed but still with the top base for protection to his people.

3. A leader or head area must also have the vision of a distant future to the welfare of his people, the need to have the soul of the spirit and the struggle to advance the region. Spirit as expressed in the symbol of the sun on the Arch Kori Apit.

4. In the aesthetics of the building Gate Kori Wedge reflecting the head, body and legs as a human. This implies that 3 (three) parts in the division such as human as a creature of the most perfectly with the concept of "students" ( $\operatorname{san}=$ human and tri= three). Perfection with relationships, with God, with our fellow humans and with nature.

\section{REFERENCES}

[1] Barker, Christ, 2000, Culture Studies ; Teori dan Praktek, Kreasi Wacana, Yogyakarta. 
[2] Berger, Arthur Asa, 2010, Pengantar Semiotika, Tanda-tanda dalam Kebudayaan Kontemporer, Tiara Wacana, Yogyakarta, p. 53.

[3] Salem WI ; 1989, Signs in Contemporary Culture, An Introduction to Semiotics, Sheffield; p. 82.

[4] Craig, Robert T, 2007, Theorizing communication, Reading Across Tradition, Sage Publication, London, LA, p. 213.

[5] Endraswara, Suwardi, 2015, Etnologi Jawa, Penelitian - Perbandingan dan Pemaknaan Budaya, Center for Academic Service, Yogyakarta, p.104-120.

[6] Giard, 2009, Semiotika Visual, Susann Vihma; p. 9.

[7] Little John, Stephen W \& A Foss, Karen, 2009, Teori Komunikasi, Theories of Human Communication, Edisi 9, Salemba Humanika, Jakarta, p-201.

[8] Mangun Wijaya, JB, 2002, Wastu Citra, Pengantar ke Ilmu Budaya Bentuk Arsitektur; Gramedia Pustaka Utama, Jakarta, p.13-15.

[9] M. S. Hartawan, I. Mantra and I. W. Widi Pradnyana, "Interpretative Analysis and Testing Statistics to test questions testing the Mobile Government questionnaire against the model of readiness and successful adoption," 2019 International Conference on Informatics, Multimedia, Cyber and Information System (ICIMCIS), 2019, pp. 147-150, doi: 10.1109/ICIMCIS48181.2019.8985195.

[10] Miller, Katherine, 2005, Communication Theories, Perspectives, Process \& Contexs, Mc Graw Hill, International, Boston USA.

[11] Nancy K. Florida, 2000, Javanese literature in Surakarta manuscripts / Vol. 2 Manuscripts of the Mangkunagaran Palace, Cornell University Ithaca, NY : Southeast Asia Program (SEAP).

[12] Sobur, Alex, 2003, Semiotika Komunikasi, Rosda Karya, Bandung, p. 15.

[13] Thomas B. Farrell, 1987, Beyond Science; Humanities Contribution to communication Theory, Handbook of Communication Science, ed, Charles, R Berger dan Steven H Caffee, Newbury Park, CA; Sage, ;p 123-139

[14] Thomas Sebeok, 1986, The Doctrine of Sign, Frontiers in Semiotic, Bloomington, Indiana University Press.

[15] Vihma, Susann \& Vakeva, Seppo, 2009, Semiotika Visual dan Semantika Produk, Teori dan Praktek Penerapan Semiotika dalam Desain, Jalasutra Karya, Bandung.

[16] Wendy Leeds-Hurwitz, 1993, Semiotic and Communication; Signs, Code, Cultures, Hillsdale, NJ, Lawrence Erlbaum; p. 53. 